\title{
SOSIALISASI PERUBAHAN PERILAKU MASYARAKAT PADA ERA PANDEMI COVID-19 DI DESA JATISARI
}

\author{
Kaskodjo Adi \\ Progam Studi Ilmu Administrasi Niaga \\ Sekolah Tinggi Ilmu Administrasi Pembangunan Jember \\ *Email: kaskodjoadi@gmail.com
}

\begin{abstract}
ABSTRAK
Berdasarkan hasil observasi di Desa Jatisari, Kecamatan Jenggawah, Kabupaten Jember, bahwa menurut informasi dari Pukesmas Kemuningsari

Kidul, Kecamatan Jenggawah Kabupaten Jember adalah kriteria yang disampaikan untuk wilayah Desa Jatisari masuk dalam zone merah yang artinya memerlukan perhatian dan kewaspadaan yang sangat serius dari pihak pejabat Satgas Penanganan Covid-19 Kecamatan Jenggawah maupun Satgas Penangan Covid-19 Kabupaten Jember. Perlu diketahui, bahwa kondisi masyarakat Desa Jatisari dalam hal tingkat kepatuhan terhadap protokol kesehatan pada umumnya dikatakan sangat kurang, meskipun pihak perangkat Desa Jatisari telah secara routine menyampaikan pesan untuk mengikuti protokol kesehatan akan tetapi ternyata masih belum adanya pemahaman sepenuhnya mengenai memberlakukan protokol kesehatan baik bagi dirinya sendiri maupun untuk kepentingan orang lain. Sosialisasi perubahan perilaku masyarakat pada era pandemi covid-19 telah menghasilkan pemahaman kepada setiap anggota Komunitas Karang Taruna Desa Jatisari, menyediakan diri untuk melakukan gerakan yang rasional, obyektivitas, dan berkelanjutan ikut memberikan penyuluhan bersama perangkat Desa Jatisari untuk memberikan pengertian, pengetahuan, tindakan pencegahan untuk menghambat meluasnya atau menyebarnya virus covid-19. Gerakan diarahkan dan diwujudnyatakan pemantauan, pengawasan dan evaluasi kepatuhan dan disiplin masyarakat untuk memperhatikan $3 \mathrm{M}$, yaitu : memakai masker, mencuci tangan, dan menjaga jarak atau wajib menghindari kerumunan di tempat umum. Kata Kunci : pemahaman, perubahan perilaku.
\end{abstract}




\section{Analisis Situasi}

Sebagai upaya mengakhiri pandemi Covid-19, Satgas Penanganan Covid-19 mengajak seluruh masyarakat menjadi garda terdepan dengan menerapkan 3 utama yaitu wajib menjaga iman, aman dan imun. Iman dimaknai dengan menjalankan ibadah sesuai agama dan kepercayaan masingmasing. Aman diartikan sebagai kepatuhan totalitas terhadap protokol kesehatan pencegahan Covid-19 yang dikenal dengan istilah $3 \mathrm{M}$ (memakai masker, menjaga jarak dan menghindari kerumunan, serta mencuci tangan pakai sabun). Sedangkan Imun harus dijaga diantaranya dengan mengonsumsi makanan bergizi, menjaga kesehatan mental, rajin berolahraga, dan beristirahat cukup.

Dalam konteks aman, perilaku wajib $3 \mathrm{M}$ harus menjadi kebiasaan seluruh masyarakat Indonesia, tanpa terkecuali. Masih cukup banyak masyarakat yang enggan melaksanakan 3M secara konsisten. Padahal, kepatuhan terhadap 3M mutlak menjadi prasyarat memutus rantai penularan
Covid-19. Hasil survei BPS selama tanggal 7-14 September 2020 lalu menunjukkan masih adanya 17 persen responden yang yakin atau sangat yakin dirinya tidak akan tertular Covid-19. Bisa berdampak terhadap pengabaian $3 \mathrm{M}$

Pembentukan bidang perilaku pada satgas penanganan Covid 19 dimaksudkan untuk menangani permasalahan penularan covid 19 di hulu, yaitu dengan mendorong percepatan perubahan perilaku masyarakat agar patuh $3 \mathrm{M}$. Dengan demikian diharapkan bahwa penyadaran dan perubahan perilaku tersebut dapat memutus rantai penulatan covid 19. Dalam melaksanakan tugasnya Bidang Perubahan Perilaku Satgas Penanganan Covid 19 didukung oleh 3 (tiga) sub bidang penting yang saling mendukung yaitu : Sub Bidang Sosialisasi, Sub Bidang Edukasi, dan Sub Bidang Mitigasi. Tim dalam bidang tersebut diharapkan mampu menggalang kolaborasi antara pemerintah, media, masyarakat, pelaku usaha, dan akademisi yang solid dan saling melengkapi. Di dalam internal satgas 
penanganan covid 19, Bidang Perubahan Perilaku memerlukan dukungan dari bidang Komunikasi Publik, khususnya untuk untuk membangun komunikasi publik yang efektif bagi masyarakat.

Selain itu, dukungan Bidang

Data dan Informasi mutlak diperlukan melalui pengumpulan data dan pemantauan indikator perubahan perilaku dilapangan. Sementara itu, koordinasi dengan Bidang Penanganan Kesehatan dibutuhkan dalam rangka menetapkan sasaran prioritas kelompok individu, keluarga, komunitas, institusi, dan wilayah yang perlu segera dilakukan intervensiperubahan perilaku, terutama bagi kelompok dengan kasus terkonfirmasi positifrelatif banyak. Kerjasama dengan Bidang Relawan dibutuhkan dalam upaya mitigasi perubahan perilaku di sasaran wilayah prioritas yang telah ditetapkan satgas.

\section{Buku Pedoman Program} Perubahan Perilaku ini menyajikan konsep dasar perubahan perilaku, perilaku apa saja yang diharapkan berubah, strategi dan sasaran perubahan perilaku, serta organisasi pelaksana. Diharapkan pedoman ini dapat menghasilkan kesamaan persepsi dan pemahaman bagi semua pihak yang terlibat dalam program perubahan perilaku. Kami sangat terbuka untuk penyempurnaan buku pedoman ini di kemudian hari. Sebagian materi edukasi 3M akan diterjemahkan dalam bahasa daerah melalui dukungan Badan Pengembangan dan Pembinaan Bahasa Kemendikbud.

Letnan Jenderal TNI Doni Monardo selaku Ketua Satgas Penanganan Covid-19 telah memberikan arahannya, kepada semua pihak yang sedang dan akan bergerak bersama dalam upaya perubahan perilaku masyarakat dengan menerapkan protokol kesehatan $\quad 3 \mathrm{M}$ untuk pencegahan/penghentian penularan Covid-19.

"Kenali dirimu, kenali musuhmu, kenali medan perangmu, seribu kali kau berperang, seribu kali kau menang”. Ungkapan tersebut relevan dengan upaya kita menyusun strategi menghadapi Covid-19 ini. Setelah mengetahui bahwa musuh 
kita "tak tampak", 3M menjadi strategi utama yang harus dilaksanakan oleh seluruh lapisan masyarakat, tanpa terkecuali. Perubahan tatanan kehidupan selama masa pandemi Covid-19 memaksa kita untuk menghadapi tantangantantangan baru dalam kehidupan sehari-hari. Pada saat seperti ini perubahan perilaku serta kesadaran masyarakat sangatlah penting. Kepatuhan menjalankan protokol kesehatan 3M dapat memutus rantai penularan dan menekan angka penyebaran Covid-19.

Satgas penanganan Covid-19 tidak dapat bergerak sendiri sehingga diperlukan kolaborasi antara pemerintah, media, masyarakat, pelaku usaha, dan akademisi (pentaheliks) untuk menjalankan perannya. Di samping itu, diperlukan strategi yang terintegrasi dan terarah, lalu diikuti koordinasi yang solid antarsatgas secara berjenjang sehingga perubahan perilaku dapat terjadi. Pelaksanaan kegiatan tentu saja harus menyesuaikan dengan karakteristik wilayah. Pedoman ini disusun sebagai dasar acuan semua satgas penanganan Covid-19 di bidang perubahan perilaku di daerah agar dapat menjalankan tugasnya dengan baik melalui fungsi edukasi, sosialisasi, dan mitigasi.

Selamat melaksanakan tugas. Pastikan perubahan perilaku dapat terlihat nyata sehingga berhasil memutus penyebaran Covid-19. Semoga Tuhan Yang Maha Esa senantiasa membimbing tiap langkah kita dalam menjalankan pengabdian terbaik bagi Indonesia tercinta.

Berdasarkan hasil observasi di Desa Jatisari, Kecamatan Jenggawah, Kabupaten Jember, bahwa menurut informasi dari Pukesmas Kemuningsari Kidul, Kecamatan Jenggawah Kabupaten Jember adalah kriteria yang disampaikan untuk wilayah Desa Jatisari masuk dalam zone merah yang artinya memerlukan perhatian dan kewaspadaan yang sangat serius dari pihak pejabat Satgas Kecamatan Jenggawah maupun Satgas Kabupaten Jember.

Perlu diketahui, bahwa kondisi masyarakat Desa Jatisari dalam hal tingkat kepatuhan terhadap protokol kesehatan pada umumnya dikatakan sangat kurang, meskipun 
pihak perangkat Desa Jatisari telah secara routine menyampaikan pesan untuk mengikuti protokol kesehatan akan tetapi ternyata masih belum adanya pemahaman sepenuhnya mengenai memberlakukan protokol kesehatan baik bagi dirinya sendiri maupun untuk kepentingan orang lain.

\begin{tabular}{cr}
\multicolumn{2}{c}{ Memperhatikan hal-hal } \\
diatas, dari pihak STIA
\end{tabular}

Pembangunan Jember menetapkan program Kuliah Kerja Nyata Tematik (KKNT) yang dilaksanakan pada bulan Nopember 2020 sampai dengan awal Januari 2021 memberikan kesempatan kepada mahasiswa untuk mengikuti kegiatan Kuliah Kerja Nyata Tematik (KKNT), juga merupakan realisasi dari rekomendasi Kepala Bakesbangpol Kabupaten Jember.

\section{Disamping} mahasiswa melakukan kegiatan KKNT di wilayah Desa Sruni, Desa Jatisari, dan Desa Jatimulyo, Kecamatan Jenggawah, maka dengan bersamaan waktunya beberapa dosen STIA Pembangunan Jember diminta melakukan pengabdian dosen kepada masyarakat di wilayah desa tersebut dengan tema berkaitan dengan meningkatkan perubahan perilaku masyarakat untuk lebih patuh dan disiplin terhadap protokol kesehatan. Setelah melakukan pendekatan dengan Kepala Desa Jatisari dan perangkat Desa Jatisari maka dosen yang melakukan kegiatan pengabdian mengadakan konsultasi, koordinasi dengan maksud untuk memperoleh kepastian langkah-langkah yang rasionalitas, obyektivitas dan berkelanjutan. Untuk itulah memperoleh kesepakatan program yang perlu dilakukan untuk memperoleh kepastian perubahan perilaku masyarakat Desa Jatisari dengan cara dan tindakan kegiatan sosialisasi perubahan perilaku, meskipun demikian kongkrit kegiatan harus memperoleh kerjasama dan dukungan dari sebagian masyarakat. Jadi dengan seijin Kepala Desa dan Perangkat Desa Jatisari maka dapatlah disepakati dengan menunjuk Organisasi Karang Taruna Desa Jatisari sebagai mitra dalam terselenggaranya kegiatan sosialisasi perubahan perilaku masyarakat Desa Jatisari. Harapannya setelah 
pelaksanaan sosialisasi kedepannya dan berkelanjutan ada gerakan nyata dari Komunitas Organisasi Karang Taruna Desa Jatisari untuk mengajak serta masyarakat mau dan mampu melakukan perubahan berkaitan dengan perubahan perilaku pada waktu pandemi covid 19 yaitu : mengenakan masker, mencuci tangan, dan menjaga jarak serta tidak boleh melakukan kegiatan yang menghadirkan massa berkerumun.

\section{Landasan Teori}

Kondisi masyarakat Desa Jatisari di era pademi covid 19 saat ini masuk pada zone merah, hal ini dikarenakan sebagaian masyarakat Desa Jatisari kurang bahkan tidak patuh pada aturan protokol kesehatan seperti memakai masker, mencuci tangan dan berkerumun sehingga melupakan untuk menjaga jarak. Hal semacam ini sudah barang tentu berakibat pada penularan semakin cepat masyarakat terinveksi virus covid 19.

Tidak patuhnya masyarakat Desa Jatisari terhadap aturan protokol kesehatan meskipun telah berulang-ulang selalu diumumkan lewat media elektronik aeperti TV, dan media cetak seperti koran, dan lain-lain. Hal ini bukan tanpa alasan, setelah dilakukan wawancara kepada beberapa warga masyarakat sebagian besar menyampaikan bahwa "virus covid 19 diyakini tidak ada".

Perlu diketahui bahwa kegiatan program sosialisasi perubahan perilaku masyarakat di era pandemi covid 19 di Desa Jatisari, Kecamatan Jenggawah, Kabupaten Jember mempunyai urgensi yang sangat luar biasa, hal ini di karenakan pihak dosen mengajak serta Komunitas Karang Taruna Desa Jatisari untuk ikut ambil bagian mensukseskan program pemerintah baik secara nasional maupun pada tingkat kabupaten bahkan sampai pada tingkat desa yang langsung bersentuhan dengan masyarakat khususnya di Desa Jatisari.

Adapun langkah dan tindakan yang hendak dilakukan kedepannya setelah kegiatan sosialisasi perubahan perilaku maka secara nyata adanya internalisasi atau mempunyai pemahaman internal pengurus Karang Taruna Desa Jatisari, kemudian ada tindakan nyata 
melalui gerakan berkelanjutan membantu perangkat desa dan Satgas penanganan covid 19 sehingga ada capaian yang lebih besar yaitu merubah paradigma, pola pikir maupun merubah prinsip atau pendapat yang keliru dalam memahami penularan virus covid 19 terhadap masyarakat luas.

\section{Sosialisasi.}

Sosialisasi mencakup interaksi sosial dan tingkah laku sosial, sehingga sosialisasi merupakan mata rantai yang penting diantara sistem sosial. Dalam buku Dasar-Dasar Sosialisasi (2004), Sutaryo, “Sosialisasi merupakan suatu proses bagaimana memperkenalkan sistem pada seseorang. Serta bagaimana orang tersebut menentukan tanggapan serta reaksinya".

Sosialisasi ditentukan oleh lingkungan sosial, ekonomi, dan kebudayaan dimana individu tersebut berada. Selain itu, sosialisasi juga ditentukan dari interaksi pengalaman-pengalaman serta kepribadiannya. Dengan sosialisasi, manusia sebagai mahluk biologis menjadi manusia yang berbudaya, cakap dalam menjalankan fungsinya dengan tepat sebagai individu dan sebagai anggota kelompok.

Tujuan sosialisasi adalah agar setiap anggota masyarakat mengetahui nilai-nilai dan norma yang ada pada suatu kelompok masyarakat. Sosialisasi adalah proses belajar yang dialami seseorang untuk memperoleh pengetahuan, keterampilan, nilai-nilai dan normanorma agar manusia tersebut dapat berpartisipasi sebagai anggota dalam kelompok masyarakat.

Perilaku.

Dalam Skinner, Menurut Notoatmodjo, (2003), : "Perilaku manusia adalah semua kegiatan atau aktivitas manusia baik yang diamati langsung, maupun yang tidak dapat diamati oleh pihak luar" sedangkan pengertian lain, bahwa perilaku adlah segala perbuatan atau tindakan yang dilakukan oleh manusia. Dan juga dibatasi sebagai keadaan jiwa untuk berpendapat, berpikir, bersikap yang merupakan refleksi dari berbagai macam aspek, baik fisik maupun non fisik. Perilaku juga diartikan sebagai suatu reaksi psikis seseorang 
terhadap lingkungannya, reaksi yang dimaksud di bedakan menjadi dua bagian, yaitu : Bentuk pasif artinya tanpa melskuksn tindakan nyata atau konkrit ; dan yang kedua dalam bentuk aktif dengan tindakan konkrit. Berdasarkan Skinner, menurut Notoatmodjo (2014), "Bahwa perilaku merupakan respon atau reaksi seseorang terhadap stimulus (rangsangan dari luar). Perilaku manusia adalah aktivitas yang timbul karena stimulus dan respons serta dapat diamati secara lagsung maupun tidak langsung.

UU No 6 tahun 2018 lahir untuk memperkuat keamanan dan kedaulatan kesehatan negara kita dari ancaman penyakit dan/atau faktor risiko kesehatan yang berpotensi menimbulkan Kedaruratan Kesehatan Masyarakat (KKM), baik dipintu masuk negara maupun di wilayah.

Direktur Surveilans dan Karantina Kesehatan, drg. R. Vensya Sitohang, M.Epid dikesempatan yang sama dalam laporannya juga mengatakan bahwa kegiatan ini dilaksanakan dengan tujuan agar tersosialisasi UU No. 6 Tahun 2018 tentang Kekarantinaan Kesehatan dan terlaksananya jejaring kerja dalam pencegahan dan pengendalian penyakit dan faktor risiko yang berpotensi KKM baik dipintu masuk maupun wilayah.

Penyelenggaraan kekarantinaan kesehatan bertujuan untuk melindungi, mencegah dan menangkal dari penyakit dn/atau faktor risiko kesehatan masyarakat yang berpotensi menimbulkan kedaruratan kesehatan masyarakat dalam rangka meningkatkan ketahanan nasional di bidang kesehatan secara terpadu, dan dapat melibatkan Pemerintah Daerah.

Dr Anung mengatakan, bahwasanya penyelenggaraan kesehatan itu haruslah dilaksanakan berazaskan pada perikemanusiaan, manfaat, perlindungan, keadilan, non diskriminatif, kepentingan umum, keterpaduan, kesadaran hukum, dan kedaulatan negara.

Untuk itudukungan semua pihak dalam penyelenggaraan kekarantinaan kesehatan sangat diperlukan baik dari pemerintah, sektor swasta, maupun elemen masyarakat. 


\begin{abstract}
Kantor Kesehatan Pelabuhan (KKP) yang merupakan unsur pemerintah pusat, berada di bawah dan bertanggung jawab kepada Direktur Jenderal Penegahan dan Pengendalian Penyakit, memiliki tugas dan tanggung jawab dalam penyelenggaraan kekarantinaan kesehatan khususnya di pintu masuk
\end{abstract} negara.

Indonesia sebagai negara anggota World Health Organitation (WHO) telah mengimplementasi IHR 2005 secara penuh. Sesuai amanah IHR 2005 yang merupakan kesepakatan global dalam pencegahan penyakit lintas negara, negara harus memiliki kapasitas inti yang kuat baik dalam kondisi rutin maupun pada saat kejadian yang dapat memerlukan respons Kedaruratan Kesehatan Masyarakat (KKM), baik di pelabuhan, bandara, maupun Pos Lintas Batas darat Negara (PLBDN).

Untuk itu kata dr Anung, upaya untuk mempercepatpelaksanaan UU No 6 Tahun 2018 tentang Kekaratinaan Kesehatan sebagaimana dalam ketentuan peralihan disebutkan bahwa pelaksanaan UU Kekarantinaan Kesehatan dalam kurun waktu tiga tahun sudah harus di laporkan ke Dewan Perwakilan Rakyat (DPR). Untuk itu upaya yang dilakukan untuk mempercepat implementasi UU No 6 Tahun 2018 tentang Kekarantinaan Kesehatan meliputi Sosialisasi UU LP/LS terkait lainnya, penyiapan peraturan pemerintah (PP) dan Peraturan Menteri Kesehatan tentang penyelenggaraan kekarantinaan kesehatan, pemenuhan sumber daya manusia, sarana prasarana dalam rangka deteksi, pencegahan, dan respons kedaruratan kesehatan masyarakat.

$\begin{array}{rrr} & \text { Dr Anung menekankan, } \\ \text { bahwa } & \text { untuk mendukung }\end{array}$ penyelenggaraan dan pelayanan kekaratinaan, maka kita perlu manfaatkan teknologi dengan sebaikbaiknya, termasuk dengan menyediakan sistem informasi yang terus dikembangkan unyuk dapat dimanfaatkan dalam penyelenggaraan dan pelayanan kekarantinaan kesehatan baik oleh pemerintah sendiri maupun masyarakat. 
Dokumen UU No. 6 Tahun 2018 tentang Kekarantinaan Kesehatan merupakan Produk Hukumyang disahkan pada tanggal 7 Agustus 2018 oleh Presiden Joko Widodo. UU ini merupakan Payung Hukum dalam mendukum pemerintah untuk melindungi gangguan kesehatan masyarakat Indonesia dari ancaman penyakit baru maupun penyekit lama yang muncul kembali.

Peraturan hukum ini sebagai bentuk respon dan tanggung jawab negara yang mengharuskan Indonesia mengikuti regulasi kesehatan internasional (International Health Regulations)tahu 2005. Regulasi tersebut mengharuskan Indonesia meningkatkan kemampuan dalam penyelidikan kesehatan serta penyelenggaraan kekartinaan kesehatan di wilayah dan pintu masuk baik di bandara, pos lintas batas, maupun pelabuhan laut.

UU ini antara lain mengatur tanggung jawab pemerintah pusat, dan pemerintah daerah, hak dan kewajiban, kedaruratan kesehatan masyarakat dan penyelenggaraan kekarantinaan kesehatan di pintu masuk. Lalu juga mengatur penyelenggaraan kekarantinaan kesehatan di wilayah, dokumen, sumber daya, informai, pembinaan dan pengawasan, penyidikan dan ketentuan pidananya terkait kekaratinaan kesehatan.

Hukuman bagi penyebar identitas pasien Covid 19, identitas pasien yang termuat dalam rekam media termasuk rahasia kedokteran yang harus disimpan dan dijaga kerahasiaanya oleh dokter yang bertugas maupun rumah sakit. Dikarenakan sifatnya yang rahasia, identias pasien termasuk kategori informasi yang tidak boleh dibuka aksesnya pada pemohon informasi publik. Jika menyebarkan identitas masien covid 19 secara sengaja dan tanpa hak, maka dokter, dokter gigi, maupun pihak rumah sakit dapat dikenai sanksipidana penjara paling lama 2 (dua) tahun dan pidana denda paling banyak Rp. 10 juta.

Kemudian pidana bagi warga "bandel" yang nekat berkerumun saat merebaknya wabah covid 19, maka Polri bersama TNI akan membubarkan masyarakat yang masih tidak mengindahkan imbauan 
pemerintah agar bekerja dari rumah dan menjaga jarak demi menekan penularan virus Covid 19. Upaya pembubaran ini menindaklanjuti Maklumat Kapolri Nomor : Mak/2/III/2020 tertanggal 19Maret 2020 yang diterbitkan menyusul semakin cepatnya penyebaran penularan virus Covid 19 di Indonesia.

Ketentuan berikutnya yaitu kaitannya seseorang dengan 2 (dua) sanksi sekaligus karena tidak memakai masker. Terhadap pelanggaran kewajiban menggunakan masker, masingmasing daerah mengatur sanksi yang berlaku, bisa jadi hukuman yang dapat dikenakan tidak hanya berupa denda, melainkan dengan tambahan hukuman lainnya misalnya teguran lisan / tertulis dan kerja sosial, seperti yang diatur di Peraturan Gubernur Kalimantan Barat Nomor 10 Tahun 2020 tentang penerapan disiplin dan penegakan hukum Protokol Kesehatan sebagai upaya pencegahan dan pengendalian Covid 19.

Adapun pidana hukum jika terjadi penangkapan terhadap orang- orang saat PSBB, salah satu provinsi yang telah disetujui sebagai lokasi PSBB terkait wabah Covid 19 adalah DKI Jakarta melalui Keputusan Menteri Kesehatan Nomor : Hk.01.07/239/2020. Gubernur DKI Jakarta telah mengatur secara rinci PSBB dalam Peraturan Gubernus DKI Jakarta Nomor 33 Tahun 2020. Penangkapan terhadap masyarakat yang melanggar PSBB menggunakan pasal 93 juncto pasal 9 UU Nomor 6 Tahun 2018 tentang Kekarantinaan Kesehatan. Perlu diingat perlu ada diskresi polisi bahwa penegakan hukum pidana bukan berarti perlu langsung melakukan penangkapaan. Ini dikarenakan penangkapan tersebut bertolak belakang keinginan Kementerian Hukum dan HAM yang ingin mengurangi penumpukan orang di lembaga pemasyarakatan dan rumah tahanan saat merebaknya wabah Covid 19.

Kemudian dalam penegakan hukum bagi warga masyarakat maka oleh Kepala Kepolisian Republik Indonesia (Kapolri) Jenderal Idham Azis telah mengeuarkan surat telegram terkait penegakan protokol kesehatan Covid 19. Surat Telegram 
Nomor : ST/3220/XI/KES.7?2020

tertanggal 16 Nopember 2020

ditandatangani oleh Kabareskrim

Konjen Listyo Sigit Prabowo. Salah

satu perintah adalah agar jajaran

kepolisian menegakkan hukum tanpa

pandang buluterhadap pelanggar

protokol kesehatan yang

mengganggu keamanan dan

ketertiban masyarakat. "Apabila

dalam penegakan Perda / Peraturan

Kepala Daerah tentang penerapan protokol kesehatan Covid 19, ditemukan adanya upaya penolakan, ketidakpatuhan atau upaya lain yang menimbulkan keresahan masyarakat dan mengganggu stabilitas kamtibmas, maka lakukan upaya penegakan hukum secara tegas terhadap siapapun", seperti dikutib surat telegam tersebut.

Dalam surat tersebut tercantum pasal-pasal yang menjadi acuan, yaitu : pasal 65 KUHP, Pasal 212 KUHP, Pasal 214 ayat (1) dan (2) KUHP, Pasal 216 KUHP, dan Pasal 218 KUHP, dan Pasal 93 UU Tentang Kekaratinaan Kesehatan.

Perlu diketahui bahwa penyebaran Corona Virus Disease 19 (Covid 19) dengan jumlah kasus dan / atau jumlah kematian telah meningkat dan meluas lintas wilayah dan lintas negara dan berdampak pada aspek politik, ekonomi, kesehatan sosial, budaya, pertahanan dan keamananserta kesejahteraan masyarakat. Dalam upaya menekan penyebaran Covid 19 semakin meluas, maka berdasarkan pertimbangan diatas maka Menteri Kesehatan dapat menetapkan Pembatasan Sosial Berskala Besar (PSBB).

Pembatasan Sosial Berskala Besar (PSBB) adalah pembatasan kegiatan tertentu penduduk dalam suatu wilayah yang diduga terinveksi Covid 19 sedemikian rupa untuk mencegah kemungkinan penyebaran Covid 19.

Untuk dapat ditetapkan PSBB suatu wilayah Propinsi, Kabupaten/ Kota harus memenuhi kriteria sebagai berikut :

Jumlah kasus dan / atau jumlah kmatian akibat penyakit meningkat dan menyebar secara signifikan dan cepat ke beberapa wilayah.

Terdapat kaitan epidemiologis dengan kejadian serupa di wilayah atau negara lain. 
Permohonan penetapan berdasarkan Peraturan Menteri Kesehatan dapat dilakukan dengan : (1) Menteri menetapkan PSBB di suatu wilayah berdasarkan permohonan Gubernur / Bupati / Walikota ; (2) Permohonan dari Gubernur maupun Bupati / Walikota disesuai dengan lingkup wilayah / daerah Propinsi atau Kabupaten / Kota setempat. Gubernur, Bupati / Walikota dalam mengajukan permohonan PSBB kepada Menteri Kesehatan harus disertai dengan data : (1) peningkatan jumlah kasus menurut waktu ; (2) Penyebaran kasus menurut waktu ; (3) Kejadian tranmisi lokal.

\section{Identifikasi dan Perumusan} Masalah

Berdasarkan pertimbangan diatas, dan juga melakukan pendekatan konsultasi dengan Kepala Desa Jatisari maka perlu dilakukan kegiatan sosialisasi perubahan perilaku masyarakat dengan harapan memiliki pemahaman berkaitan dengan Pandemi Covid 19.
Mengingat keadaan Desa Jatisari masuk pada zone merah, maka dapat dirumuskan permasalah sebagian besar masyarakat Desa Jatisari, yaitu :

Kurang memiliki kesadaran untuk melakukan protokol kesehatan seperti memakai masker, mencuci tangan, dan menjaga jarak, disingkat $3 \mathrm{M}$.

Tidak patuh dan disiplin untuk melakukan kegiatan $3 \mathrm{M}$.

Belum ada partisipasi kelompok komunitas masyarakat untuk menyampaikan pesan kepada masyarakat berdasarkan katagori tingkat golongan yang ada di kalangan masyarakat.

\section{Tujuan Kegiatan}

Adapun tujuan dan manfaat kegiatan pengabdian dosen dengan kegiatan sosialisasi tersebut adalah : Mengajak serta kelompok komunitas masyarakat dalam hal ini Karang Taruna Desa Jatisari untuk ikut berpartisipasi dalam kegiatan yaitu : memakai masker, mencucui tangan, dan menjaga jarak.

\section{Manfaat Kegiatan}


Adapun manfaat, memiliki pemahaman setelah mengikuti sosialisasi perubahan perilaku melalui kelompok komunitas masyarakat dalam hal ini Karang Taruna Desa Jatisari selanjutnya diharapkan ada gerakan ikut memantau, mengawasi, dan melakukan tindakan seperti : persuasif dan edukasi secara terus menerus.

Tujuan sosialisasi adalah melalui Komunitas Karang Taruna Desa Jatisari yang ditunjuk sebagai mitra agar setiap anggota masyarakat mengetahui nilai-nilai dan norma yang ada pada suatu kelompok masyarakat. Sosialisasi adalah proses belajar yang dialami seseorang untuk memperoleh pengetahuan, keterampilan, nilai-nilai dan normanorma agar manusia tersebut dapat berpartisipasi sebagai anggota dalam kelompok masyarakat.

\section{Kerangka Pemecahan Masalah}

Berdasarkan observasi dan pengamatan bahwa Desa Jatisari, Kecamatan Jenggawah tergolong masuk zone merah juga telah di pertegas oleh Kepala Desa Jatisari , hal ini juga dinyatakan berdasarkan data dari Puskesmas Desa Kemuningsari Kidul, Kecamatan Jenggawah. Adapun salah satu indikator yang sangat kuat dikarenakan pada umumnya masyarakat Desa Jatisari berperilaku kurang patuh pada protokol kesehatan dalam hal ini sering dikenal dengan $3 \mathrm{M}$.

Kebijakan pemerintah desa, pihak Kepala Desa bersama Perangkat Desa Jatisari sering melakukan perkunjungan ke dusundusun dan menjumpai masyarakat din tempat tersebut untuk melakukan pengumuman tentang adanya virus covid 19 yang sangat berbahaya terhadap kehidupan manusia bahkan menyebabkan kematian jika tidak patuh pada protokol kesehatan.

Pihak Satgas Kecamatan Jenggawah, Muspika bersama tenaga medis dari Puskesmas Desa Kemuningsari Kidul dan Puskesmas Kecamatan Jenggawah disamping memberikan penyuluhan juga telah melakukan tindakan pengawasan dan pemantauan. Namun demikian masih terdapat kurang perhatian dari masyarakat untuk mematuhi perintah 
Petugas Satkas Kecamatan Jenggawah.

Menurut pengamatan, evaluasi dari Kepala Desa dan Perangkat Desa Jatusari, demikian juga pernyataan dari Petugas Satgas Kecamatan Jenggawah, nampaknya ada pemahaman bahwa virus covid 19 tidak ada.

\section{Kehadiran Dosen STIA}

Pembangunan Jember yang telah diprogram untuk melakukan kegiatan pengabdian masyarakat di Desa Jatisari, yaitu melalui kegiatan program sosialisasi perubahan perilaku masyarakat dalam menghadapi virus covid 19, dengan mengajak salah satu komponen atau kelompok masyarakat yang ada di Desa Jatisari untuk mengundang hadir dan mengikuti kegiatan sosialisasi tersebut. Adapun harapan yang ingin dicapai melalui sosialisasi ini perlu adanya pertukaran pengetahuan sehingga kemungkinan adanya masyarakat tergugah unu patuh terhadap protokol kesehatan.

Dalam program kegiatan sosialisasi tersebut dosen STIA Pembangunan Jember yang ditugasi melakukan kegiatan sosialisasi melakukan pendekatan dengan pihak Komunitas Karang Taruna Desa Jatisari sebagai mitra untuk bersamasama mendukung, keikut sertaan menyelenggarakan sosialisai tersebut. Tindakan terakhir setelah sosialisasi ini adanya pemahaman yang diperoleh kelompok masyarakat yang telah mengikuti kegiatan sosialisasi tersebut dan kemudian kedepannya ada gerakan partisipasi yang dilakukan oleh Pengurus bersama anggota Komunitas Karang Taruna Desa Jatisari melakukan pemantauan, monitoring, pengawasan dan evaluasi. Kemudian hasilnya dilaporkan kepada Kepala Desa Jatisari.

\section{Khalayak Sasaran}

Kegiatan pengabdian dosen telah ditetapkan pada hari Sabtu tanggal 21 Nopember 2020, di mulai pukul 10.00 dan berakhir pukul 11.30 ; Sedangkan tempat pelaksanaan di Balai Desa Jatisari, Kecamatan Jenggawah, Kabupaten Jember.

\section{Metode Kegiatan}


Berdasarkan usulan dari pihak dosen pelaksana kegiatan pengabdian disamping memperoleh pesetujuan adanya kegiatan sosialisasi maka juga memperoleh kesepakatan awal dengan pihak pemerintahan desa, dalam hal ini Kepala Desa Jatisari maka untuk Konkritnya sasaran sebagai peserta untuk masyarakat diwakili oleh Komunitas Organisasi Karang Taruna Desa Jatisari.

Kemudian pada saat pelaksaan, menurut rencana peserta sosialisasi yang diharapkan hadir dalam undang yaitu terbagi : anggota Karang Taruna berjumlah 10 (sepuluh) orang dan dari pihak perangkat desa 2 (dua), namun dari anggota Karang Taruna tidak bisa hadir dan ijin 1 (satu) orang, sehingga jumlah peserta yang mengikuti kegiatan program pengabdian sosialisasi berjumlah 11 (sebelas) orang.

Metode ceramah diartikan sebagai penyajian pelajaran oleh seorang penceramah dengan cara memberikan penjelasan secara lisan kepada orang yang mendengarkannya. Ceramah merupakan suatu metode yang paling populer dan paling banyak digunakan oleh para pengajar.

Menurut Wina Sanjaya (2006 : 147), "Staregi Pembelajaran Berorientasi Standar Proses Pendidikan". Jakarta, Kencana Prenada Media Group. menjelaskan bahwa metode ceramah merupakan cara menyampaikan pembelajaran dengan penuturan secara lisan atau penjelasan secara langsung kepada masyarakat.

Dalam ceramah pada saat pelaksanaan kegiatan sosialisasi dilengkapi dengan materi sosialisasi dan dibagikan kepada seluruh peserta yang mengikuti pada saat berlsngsungnya sosialisasi tersebut.

Pengertian diskusi adalah suatu onteraksi komunikasi yang terjadi antara dua oran atau secara berkelompok dimana tujuannya untuk membahas suatu tema atau topik tertentu sehingga menghasilkan suatu kesepakatan pendapat. Ada juga memberikan pengertian bahwa suatu proses pertukaran pikiran, gagasan, dan pendapat yang dilakukan oleh dua orang atau lebih, untuk mendapatkan suatu kesimpulan atau kesepakatan bersama. 


\section{Evaluasi Kegiatan}

Perlu diketahui bahwa sebelum berakhir pelaksanaan sosialisasi maka telah memperoleh kesepahaman dan kesepakatan bahwa tindak lanjut dan tindakan yang perlu dilakukan oleh anggota organisasi Komunitas Karang Taruna adalah adanya gerakan yang positih, rasional, obyektivitas, dan berkelanjutan dalam bentuk memberikan penyuluhan, monitoring dan evaluasi, dan sudah barang tentu bersama perangkat Desa Jatisari.

\section{DAFTAR PUSTAKA}

Sutaryo, 2004., "Sosialisasi merupakan suatu proses bagaimana memperkenalkan sistem pada seseorang. Serta bagaimana orang tersebut menentukan tanggapan serta reaksinya". Dasar-Dasar Sosialisasi.

Notoatmodjo, 2003. "Perilaku manusia adalah semua kegiatan atau aktivitas manusia baik yang diamati langsung, maupun yang tidak dapat diamati oleh pihak luar" Skinner.

Notoatmodjo, 2014, "Bahwa perilaku merupakan respon atau reaksi seseorang terhadap stimulus (rangsangan dari luar). Perilaku manusia adalah aktivitas yang timbul karena stimulus dan respons serta dapat diamati secara lagsung maupun tidak langsung”. Skinner,

.Wina Sanjaya, 2006 : 147, “ Staregi Pembelajaran Berorientasi Standar Proses Pendidikan”. Jakarta, Kencana Prenada Media Group.

Undang-Undang Nomor 6 Tahun 2018.

Hukum Pidana Pada Covid 19.

Peraturan Menteri Kesehatan Nomor 9 Tahun 2020. 